\title{
Exploration on the Construction of the Cooperative Education System of Ideological and Political Education in Colleges and Universities
}

\author{
Qiang Zhang, Changxing Xie
}

Sichuan Agricultural University, Academy of Marxism, Ya'an, Sichuan, 625014

Keywords: synergetic theory; ideological and political education; path exploration

\begin{abstract}
The convening of ideological and political work conferences in colleges and universities all over the country has led people from all walks of life to gradually realize the necessity and importance of ideological and political education. However, the current internal and external ideological and political education system in our country has the incomplete system and mechanism, which leads to the problems of divergence, closeness and low efficiency of ideological and political education in colleges and universities. The universality and openness of the theory of collaboration provide a good theoretical basis and research method for the development of ideological and political education in colleges and universities. Under the guidance of synergetic theory, the ideological and moral level of college students can be further improved to help them establish the correct "three views", and help explore the ideological and political education mode and path adapting to the new era.
\end{abstract}

\section{Introduction}

Ideological and political education in colleges and universities plays a leading role in the development of higher education. On December 7, 2016, General Secretary Xi Jinping's speech at the National Conference on Ideological and Political Work in Colleges and Universities emphasized: "We must insist on using the Lide Shuren as a central link and ideological and political work throughout the entire process of education and education to realize the entire process of educating people. We will educate people and work hard to create a new situation for the development of our country's higher education." [1] Only by involving ideological and political education in the entire process of teaching through people's growth and development processes can we cultivate values that are consistent with the values of socialist modernization. " The Outline of Moral Education in China's Ordinary Higher Education Institutions (Trial), formulated by China in 1995, has enabled our colleges and universities to initially establish the institutional mechanisms for unified leadership by party committees, coordinated administration by party and government groups, full-time and part-time teacher cooperation, and self-education by students. Under the requirements of this institutional mechanism, the Party's Organization Department, Propaganda Department, Student Affairs Office, Academic Affairs Office, Communist Youth League and other party and government departments cooperate with each other and have clear functions. The ideological and political teachers and teachers of related professional courses conduct front-line teaching work. However, in the actual teaching operation process, due to the difference in management between the school administrative system and the teaching system, the various departments of the ideological and political education failed to coordinate and cooperate, and lacked the combined effect of education, and it was difficult to meet the requirements of the top-level design. Especially since the 19th National Congress, President Xi Jinping has put forward higher requirements for ideological and political education in colleges and universities. How to improve the effectiveness of ideological and political education in colleges and universities and how to achieve the educational goal of ideological and political education requires the organic cooperation of governments, enterprises, schools, and families. With the cooperation of various subjects and the establishment of a rational cooperative education system, it is possible to explore a new model of ideological education in universities that is adapted to the requirements of the new era. 


\section{Collaboration Theory and the Possibility of Combining with Ideological and Political Education}

The theory of collaboration was first proposed by Professor Hacken of the University of Stuttgart in the Federal Republic of Germany in 1971. The subsequent works, Synergetic Introduction and Advanced Synergy, systematically discussed the theory and was applied in multidisciplinary research. On the basis of the emerging theory that has been gradually developed and developed.

Collaboration theory is based on the latest modern research results-information theory, system theory, cybernetics, and catastrophe theory. It draws on the beneficial parts of a large number of structural dissipation theories and adopts modern methods of statistics and dynamics. The analysis of various fields puts forward the theory of multidimensional phase space, establishes a set of scientific treatment plans, and reveals the laws of transformation of various systems from disorder to order. Collaboration theory is based on coordination and coordination at the macro level, emphasizing the co-evolution between the various parts of the system and the application of integrated methods, focusing on the overall coordination of the operation of various subsystems, and advocating the integration of resources, optimization of systems, and promotion of development in collaboration. . In synergetic theory, synergy refers not only to the coordination, cooperation, and union among subsystems, but also includes a broad relationship of competition and cooperation. [2]

Collaboration theory has universal applicability. Modern theoretical results suggest that in the living natural world, all systems are open; in the process of system evolution, the collective movement forms enable different structures to be realized. From this, we can see that the principles and laws of structural formation revealed by synergetic theory not only provide new principles and methods for us to study the natural world, but also for the development of our study of human thought. It is precisely because of the universality of the theory of collaboration that the introduction of synergy theory into ideological and political education research will inevitably be of inspiration to the development of ideological and political education theory and to solving problems in practical ideological and political education, and provide a new theoretical perspective and thinking model. .

Collaboration theory is open. Collaboration theory is the main component of the self-organizing principle and emphasizes the exchange of material, information, and energy with the outside world. Any system that remains isolated or closed will result in the collapse or separation of its internal orderly state. Collaboration theory emphasizes the communication, integration and unification between the internal systems and the system and other external systems. The ideological and political education system requires attention to the openness of the system, whether it is an open environment or an open mind between the subjects within the ideological and political education, between the subject and the object, and between the ideological and political education system and the external environment. Ideological and platform, the main body of ideological and political education must learn from the social environment in the knowledge and control society-led ideology, and the object of ideological and political education also need to obtain information and knowledge from an open society. The subjects and objects that make up the ideological and political education system are products of the social environment. Only when the two are open to each other and exchange information and materials can they continuously advance the benign operation of the ideological and political education system.

In short, ideological education in colleges and universities is a systematic project, not a person or a person in a position can do. The introduction of synergetic theories and the construction of a synergistic mechanism for ideological and political education are conducive to the coordination and cooperation of all parts of the ideological and political education and to the full use of their respective functions. This will greatly help the orderly, lasting and highly efficient development of ideological and political education. 


\section{Problems in the Cooperative Education System of Ideological and Political Education in Colleges and Universities}

In his "Outline on Feuerbach", Marx pointed out that "the essence of man is not an abstraction inherent to a single person. In its reality, it is the sum of all social relations."[3] This is a position from practice. Explain to us that people have social attributes. People's growth and development cannot be separated from the influence of society. The society provides conditions for human development and also restricts people's development. The current people are in a globalized, informatized, networked, and diversified society. People can obtain various kinds of information in a timely and convenient manner. These massive amounts of information are mixed, and have a profound influence on the effectiveness of ideological and political education. Therefore, how to shape the nature of man through ideological and political education and improve the ideological realm, political quality, moral quality, ideals and beliefs of the university students to meet the requirements of the new era for college students, and at the same time promote the free and comprehensive development of university students has become the current ideological and political The mission and goals of education. Since the central government has increased its emphasis on ideological and political education, ideological and political education in colleges and universities has achieved certain results. However, due to the obstacles in the internal institutional mechanisms of colleges and universities, the lack of in-depth cooperation among various educational subjects has made it impossible for ideological and political education to fully play its role. Specific performance in the following areas:

From the inside of the ideological and political education system of colleges and universities, the school administrative management department and the ideological and political education of college students are separated, and a perfect coordination mechanism has not yet been established. Propaganda Department, Party workers, Communist Youth League committees, etc., and ideological and political teachers and counselors are independent of one another. They lack the sharing of ideological and political education work information, lack long-range actions, and lack communication channels and linkage mechanisms. All departments do not have an objective and comprehensive working mechanism for students' moral education assessment. They often use the results of the courses as the assessment criteria for students' moral education, and have not formed a systematic and complete assessment and evaluation standard.

From the outside of the ideological and political education system in colleges and universities, there are obstacles to the coordinated development of families, universities, society, enterprises, and colleges and universities. The ideological and moral qualities of college students are inseparable from the education of each family. The exchange of experiences and methods among colleges and universities is also an important way for the ideological and political education of college students to achieve the desired results. The social atmosphere affects the effectiveness of school ideological and political education, and ideological and political education. The combination of university student business practice is an important factor affecting the effect of ideological and political education. As far as the current situation is concerned, the four are separated from each other and lack a platform for cooperation and interaction. Under the influence of diverse social values, especially the cyber culture in the information age, the ideological and political education of undergraduates has created a powerful Impact.

From the theoretical platform of ideological and political education in colleges and universities, the ideological and political education theory teaching platform with ideological and political theory as its core has not fully exerted the effects of its theoretical education. Departmental colleges and universities do not attach importance to the development of ideological and political education courses and the choice of teachers. Insufficient classes are offered, or courses related to the ideological and political programs are not offered. The insufficiency of theoretical education is insufficient to educate the students' ideological and moral concepts, and students cannot form correct outlooks on life, values, and world views, and ultimately affect the quality of undergraduate education. 
From the perspective of the educational platform for ideological and political education in colleges and universities, some colleges and universities lack the platform for social practice of college students, which has led to the social practice that many schools require. The lack of cooperation agreements and platforms between some colleges and universities, enterprises, and government institutions has caused many students to fail to find good internships. Some colleges and universities have loose management in social practice, and students respond to internship requirements through improper means.

From the ideological and political education network education platform for colleges and universities, the construction of the network ideological education platform for college students lags behind. The Internet has become an important part of every college student's life, closely related to the life of college students, and mastering the ideological and political education of the Internet. The important position is an important bastion to ensure the effectiveness of ideological and political education. The ideological and political educators should keep pace with the times, use the discourse system of ideological and political education in a timely manner to occupy this position, use the correct values to lead public opinions, guide students, and expand the field of ideological and political education.

It can be seen from the above situation that the institutional mechanisms for the collaborative work of the ideological and political education system in colleges and universities need to be improved, and the platform for synergistic educating people needs to be established and improved. Only when collaborative education is carried out in the context of the big thinking system can we innovate the theory of ideological and political education. With practice, we can better play the educational effect of ideological education.

\section{The Construction Path of the Cooperative Educational System of Ideological and Political Education in Colleges and Universities}

The coordinated development of ideological and political education in colleges and universities refers to the political workers among ideological and political educators and administrative departments in colleges and universities, ideological and political educators in different universities and colleges and colleges and universities, as well as political workers in university and social science research institutes and enterprises. Focusing on the training of different professional talents and the ideological and political issues in practical work, using their own advantages in resources and capabilities, in the government propaganda departments, ideological and political research collaboration associations, civic organizations, families and other related subjects in coordination Next, we work together to conduct R\&D, so as to strive for innovative activities that have made major breakthroughs in the study of ideological and political education in universities: Schools, families, companies, governments, and other social organizations need to break through the limitations of departmental systems among the relevant staff of ideological and political education through innovation. The ideological and political education management and collaboration, team cooperation, ideological and political education resources sharing, the use of modern information technology and timely interactive communication, and can carry out external collaboration, and ultimately achieve the coordinated development of ideological and political education.

The establishment of the goal of coordinated development has set the direction for the development of ideological and political education, and has also provided action guidelines for the development of ideological and political education. The main body of ideological education in colleges and universities embraces common development goals, and can focus on each other to promote each subject to the same goal in a different position and courageously move forward, to better promote the realization of ideological and political education goals. The goal of coordinated development of ideological and political education is not only to consider the difference between it and the general enterprise and management objectives, but also to consider the object of ideological and political education - the personality of college students and the need for the growth of knowledge. Considering various factors, it is necessary to strengthen the internal and external cooperation of the ideological and political education system and coordinate development. 
According to the different needs of social development, advance with the times and determine different levels of goals. We must establish the goals of the macro level from the need for the development of countries with strong talents and the need for the full and free development of college students - to upgrade the ideological and moral qualities of college students and to cultivate new "four talents" suited to the needs of social development; from the coordination of regions, enterprises, development and The development of college students only needs to establish the meso-level goals to cultivate the professional practitioners; from the need to harmonize student family harmony and the personal growth of students to establish micro-level goals to cultivate ethical and cultural new people.

The good ideological and political qualities of college students are not things that happen overnight, nor can they be achieved by banging on drums. They need to accumulate in the process of studying in universities, acquire knowledge in the process of continuous learning, and continue to improve their ideological and moral qualities. On the one hand, colleges and universities should base themselves on the school's historical traditions and characteristics of running schools, tap the superior resources of the university, and provide the university with practical resources for ideological and political education. On the other hand, ideological and political educators in various universities should treat their schools with an open mind, strengthen exchanges and cooperation with other institutions, actively learn from the excellent experiences of other universities, and explore ideological and political issues that suit their development. In short, when universities collaborate in the development of school resources, they should also establish a collaborative development mechanism with other universities to promote the sharing of ideological and political education resources and the sharing of experiences, so as to improve the quality of personnel training in colleges and universities as a whole.

The main task of ideological and political education in colleges and universities is to train qualified personnel in line with the needs of social development. In order to further promote the healthy and comprehensive growth of college students, schools must be targeted to establish a more comprehensive cooperative education system. The establishment of this mechanism requires the participation of all parties. It requires not only the unified planning of all departments and staff in universities, but also the students' own efforts. At the same time, it needs the unity and integration of social institutions and families, and further cooperation in the process of cooperation. Improve colleges' ability to cooperate and educate people. For the establishment of the evaluation mechanism of ideological and political education in colleges and universities, it is necessary to adhere to the principle of being people-centered. It is not possible to use student achievement as the only indicator to evaluate students, and students must pay attention to the overall development of their health. In the process of implementing the evaluation mechanism, we adhere to the combination of feedback and evaluation, adhere to the combination of ideological and political education and individual student needs, understand student feedback in the evaluation mechanism, and clarify the students' state of mind from these feedback questions. And use this as a breakthrough to improve and optimize ideological and political education methods and methods.

The university's collaborative ideological and political education involves the future development of the country and is the inevitable choice for the country's personnel training. In order to achieve coordinated development, it is necessary to create a good platform to provide necessary material guarantees for achieving coordinated development. The construction of the platform needs to be coordinated with various aspects. It is necessary to consider the problems in real life as well as the problems in the virtual world. Therefore, the construction of the platform must be combined with online and offline. Online needs to establish a collaborative development network platform and a collaborative development platform need to be established under the line. The network platform needs to establish a system that is responsible for arranging and managing subject ideological and political education courses for subjects, and also needs to establish a system for mutual communication and sharing between subject and object; a practical platform is more to provide opportunities for object practice, and to provide ideological and political education. The learned theory is combined with social reality. Through the collaborative development of online and offline 
platforms, we will further promote the further improvement of the ideological and moral quality of the object, achieve the goal of ideological and political education, and better serve the society.

In order to realize the goal of synergetic ideological and political education in colleges and universities, the establishment of a ideological and political education team with strong ideological style, solid professional knowledge, and strong business abilities is the foundation for achieving coordinated development, and it is also a necessary guarantee for the advancement and development of college students. In the process of implementing coordinated development, the main body of implementation is diverse and the levels are diversified, so the methods and effects of training are also very different, and the results of ideological and political education for college students may be uneven. The construction of the collaborative development team can make up for the fact that each subject has its own politics, and can analyze the ideological and political conditions of the educated people in a meticulous and comprehensive manner. Teams can collaborate with each other and work together to implement different educational programs for different educational objects. Different education subjects, under unified standards, can achieve the improvement of educational effectiveness and realize the educational goals of ideological and political education. The construction of the team requires a unified arrangement of the school, the selection of teachers with a certain affinity and popularity among students, or outstanding ability in the process of administrative management. The backbone of outstanding business is to select outstanding talents only with the support and encouragement of the school. The team can cultivate outstanding talents, and can coordinate all factors to promote the realization of ideological and political education goals.

\section{References}

[1] Adhere to the Litshu people as a central link [N], Guangming Daily, 2016-12-09 (01).

[2] Zeng Changqiu, Yin Hongyu. Marxism needs ideological and political education in the perspective of theory [J]. Ideological Education Research, 2013, (5)

[3] "Selected Works of Marx and Engels" [M], Vol. 1 p. 18. 